\title{
Inactive disease and remission rates after intraarticular steroids as initial therapy for juvenile idiopathic arhtritis (JIA)
}

\author{
JO Sato ${ }^{*}$, TAP Fernandes, CB Nascimento, RG Brito, C Saad-Magalhães \\ From 18th Pediatric Rheumatology European Society (PReS) Congress \\ Bruges, Belgium. 14-18 September 2011
}

\section{Objective}

Describe rates of Inactive Disease (ID) and remission on (CRM) and off medication (CR) after intraarticular steroids (IAS) as initial therapy for JIA.

\section{Methods}

Frequency of ID, CRM and CR were calculated and estimated by survival curves for all subjects with initial treatment of IAS until additional therapy with DMARDs or biologics was added.

\section{Results}

A review of 110 IAS sessions (246 treated joints) in 72 subjects was carried out. Median (IQR) follow-up duration was 4.3 years $(2.7-6.1)$. JIA (ILAR) categories were: persistent (55.6\%) and extended oligoarthritis (27.8\%), enthesitis related arthritis (8.3\%), undifferentiated $(6.9 \%)$ and psoriasic (1.4\%). Knee (s) were treated in $47.3 \%$, both knees and ankles in $38.2 \%$, and only ankle (s) in $14.5 \%$. Triamcinolone hexacetonide was used in $86.1 \%$. ID rates after the first IAS $(n=72)$ was $55.6 \%$, at median (IQR) 2.4 months $(1.1-6.6)$. After the first IAS session, CRM and CR were observed in $25 \%$ and $22.2 \%$, respectively. After the second $(n=22), I D$, CRM and CR occurred in $45.5 \%, 13.6 \%$ and $9.1 \%$, respectively, and after the third $(\mathrm{n}=12), 16.7 \%, 0 \%$ and $8.3 \%$, respectively. Overall outcome was: CR in $23.6 \%$, CRM in $4.2 \%, 18.1 \%$ lost follow-up, $34.7 \%$ added DMARD and 4.2\% DMARD plus biologic. Median survival for inactive disease, CRM and CR were 6.2, 11.5 and 21.6 months.

\footnotetext{
* Correspondence: julianasato@fmb.unesp.br Pediatric Rheumatology Unit, Botucatu Medical School, São Paulo State University (UNESP), Brazil
}

\section{Conclusions}

Inactive disease state occurred in about $50 \%$ and $C R$ in $23.6 \%$ of patients. Effectiveness of IAS tends to decreased with repeated injections, and this might be considered to step up treatment.

Published: 14 September 2011

doi:10.1186/1546-0096-9-S1-P207

Cite this article as: Sato et al:: Inactive disease and remission rates after intraarticular steroids as initial therapy for juvenile idiopathic arhtritis (JIA). Pediatric Rheumatology 2011 9(Suppl 1):P207.

Submit your next manuscript to BioMed Central and take full advantage of:

- Convenient online submission

- Thorough peer review

- No space constraints or color figure charges

- Immediate publication on acceptance

- Inclusion in PubMed, CAS, Scopus and Google Scholar

- Research which is freely available for redistribution 